\title{
THE AUTHORITY OF THE BEN JONSON FOLIO OF 1616. ${ }^{1)}$
}

Ben Jonson's Every Man out of his Humour was first acted in 1599, and printed for the first time in the year following.

Of this comedy, Gifford, the editor of Ben Jonson's works and one of his warmest admirers, says that, "as a whole, it is very deficient in interest". It is indeed tedious enough in all conscience, and we can hardly be surprised to hear that Ben Jonson's contemporaries did not think much of it, as may safely be concluded from three passages in the first quarto edition of 1600, "printed for Nicholas Linge". ${ }^{2}$ )

After a brief characterisation of the persons represented, and preceding the play itself, the following address to the reader is printed on page A 3 of this quarto edition:

It was not neare his thought that hath published this, either to traduce the Anthour; or to make rulgar and cheape, any the peculiar and sufficient deserts of the Actors: but rather (whereas many Censures flutter'd about it) to giue all leaue, and leisure, to indge with distinction.

Quite possibly, these words were written by Ben Jonson himself, though the form of the notice was of course meant

1) The paper here submitted to the reader is a translation, and to a certain extent a recast, of an article written in Dutch, entitled "Een Merkwaardig Geval", which Dr. Van Dam contributed to "Herinneringsbundel Professor S. S. Rosenstein bij gelegenheid van zyn aftreden als hoogleeraar aan de Leidsche Universiteit aangeboden door dankbare leerlingen en vrienden. Leiden, Eduard Ydo. 1902".

2) The copies of the 1616 Folio and of the Quarto of 1600 which we have used, are both of them in the Royal Library at the Hagne.

Anglia. N. F. XIV. 
to create the impression that it uwas Nicholas Linge who was addressing the readers of the boook brought out by him. It was quite usual for publishers to) address the reading public in this manner. Whether writtem by Ben Jonson himself, or by his publisher, at all events this appeal to the public, especially the words in parenthesees, puts it beyond doubt that the play had been anything but a decided success on its first performance.

We have a right to draw the same conclusion from a couple of lines on page $Q 3$ verso, of the quarto edition - we shall cite the precise words furtherr on - in which Ben Jonson candidly informs us that he has ( changed the closing scene of the play, because its original concltusion seemed to be distasteful to many of the spectators.

The new closing scene runs : as follows (Macilente loq.)

Page Q2 verso,

1. 22. Why here's a change: Noow is my soule at peace, I am as empty of all Ennuie now, As they ${ }^{1}$ ) merrit to be eenuied at.

25. My Humor (like a flame)) no longer lasts Than it hath stuffe to feeed it, and their vertue, Being now rak't vp in eembers of their Folly, Affords no ampler Subiect to my Spirit; I am so farre from maliccing their states,

30. That I begin to pittie them: it greeues me To thinke they have a bbeing; I could wish They might turne wise rvpon it, and be sau'd now, So Heanen were pleas'd : : but let them vanish Vapors. And now with Aspers tonngue (though not his shape)

35. Kind Patrons of our spoorts (you that can indge, And with discerning thooughts measure the space

Page Q3, 1. 1. Of our straunge Muse inn this her Maze of Humor, You, whose true Notionss doe confine the formes And nature of sweete Proesie) to you I tender solemne and moost durious ${ }^{2}$ ) thanks,

5. For your stretch ${ }^{3}$ ) patiennce and attentiue grace.

We know (and we are ppleas'd to know so much) The Cates that you hauee tasted were not season'd For euery vulgar Pallat,; but prepar'd To banket pure and appprehensiue eares:

1) they misprint for they of.

9) durious misprint for duteous.

s) stretch misprint for stretch'd. 
10. Let then their Voices speake for our desert;

Be their Applause the Trumpet to proclaime Defiance to rebelling Ignorance, And the greene spirits of some tainted Few, That (spight of pittie) betray ${ }^{1}$ ) themselues

15. To Scorne ond ") Laughter; and like guiltie Children, Publish their infancie before their time, By their owne fond exception: Such as these We pawne 'hem to your censure, tell ${ }^{3}$ ) Time, Wit, Or Obseruation, set some stronger seale

20. Of iudgement on their indgements; and entreat The happier spirits in this faire-fild Globe, (So many as haue sweet minds in their breasts, And are too wise to thinke themselues are taxt In any generall Figure, or to vertuous

25. To need that wisedomes imputation:)

That with their bounteous Hands they would confirme This, as their pleasures Pattent: which so sign'd, Our leaue nnd () spent Endeuours shall renue Their Beauties with the Spring to smile on you.

FINIS.

The first twelve lines of this passage, lines 22-33 of page $Q 2$ verso, form the new closing scene, properly so called, and the remaining lines, beginning with 1.34 , which ought to have been marked off from the others in some way or other, constitute a new epilogue. This new epilogue contains the third evidential passage from which it may be inferred that in 1599 the spectators had by no means gone into raptures over the play. Ben Jonson's sense of his own worth came dangerously near to overweening self-conceit. If the audience did not admire his plays, the cause was according to him in their defective knowledge and their want of culture. Nor did he shrink from boldly telling them so to their faces: their marks of disapproval were the utterances of a "rebelling Ignorance", to which he bade defiance by an appeal to the

1) betray misprint for did betray.

2) ond misprint for and.

8) tell misprint for till.

-) leawe nnd misprint for leane and. Lean is here used in the sense of poor, just as in my lean and low ability (Shakespeare, Twelfthnight III, 4, 378). We mention this, because up to now all editors of Ben Jonson's works have unwisely replaced leaue nnd by leaven'd. 
"pure and apprehensive ears" of the "happier spirits", who were competent to pronounce judgment on "Cates that were not seasoned for every vulgar palate".

After the "Finis" we get in the quarto edition, first a statement of the motive that had led Ben Jonson to change the closing scene, then a defence of the original version, and lastly the original version itself. The reason why many persons disapproved of the closing scene in its first form, Jonson gives in Greek: he evidently thought it undesirable to admit the illiterate mob to his confidence. As this point is of some importance for what we shall have to discuss further on, we would request the student to read the last pages of the quarto edition, which we now print, without attending to the Greek parenthesis in the opening lines.

Page Q3 verso:

It had another Catastrophe or Conclusion, at the first Playing: which (DIA TO TEN BASILISSAN PROSOPOPOESTHAI) many seem'd not to rellish it; and therefore 'twas since altered: yet that a right-eyd and solide Reader may perceiue it was not so

5. great a part of the Heauen awry, as they would make it: we request him but to looke downe vpon these following Reasons.

1. There hath bene President of the like Presentation in diuerse Playes: and is yeerely in our Citie Pageants or shewes of Triumph.

10. 2. It is to be conceiu'd, that Macilente being so strongly possest with Enuie, (as the Poet here makes him) it must be no sleight or common Obiect, that should effect so sodaine and strange a cure vpon him, as the putting him cleane out of his Humour.

3. If his Imagination had discourst the whole world ouer for an $\mathrm{Ob}$ -

15. iect, it could not haue met with a more Proper, Eminent, or worthy Figure, then that of her Maiesties: which his Election (though boldly, yet respectiuely) us'd to a Morall and Mysterious end.

4. His greedinesse to catch at any occasion, that might expresse his

20. affection to his Soueraigne, may worthily plead for him.

5. There was nothing (in his examin'd opinion) that could more neare or truly exemplifie the power and strength of her inualuable Vertues, then the working of so perfect a Miracle on so oppos'd a Spirit, who not only persisted in his Humor, but was now come

25. to the Court, with a purpos'd resolution (his Soule as it were now drest in Ennie) to maligne at anything that should front him when sodainly (against expectation, and all steele of his Malice) the very wonder of her Presence strikes him to the earth dumbe, and astonisht. From whence rising and recouering heart, his Passion

30. thus vtters it selfe. 
Maci. Blesse 1), JDiuine, Vnblemisht, Sacred, Pure

Glorious immortall, and indeed Immense;

0 that I had a world of Attributes,

Page Q4, 1. 1. To lend or adde to this high Maiestie:

Neuer till now did Wbiect greet mine eyes

With any light Conttent: but in her Graces

All my malitious Porwers haue lost their stings:

5. Enuie is fled my Soule at sight of her,

And shee hath chac'd all blacke thoughts from my bosone,

Like as the Sunne dioth darknesse from the world.

My streame of Humcor is run out of me:

And our ${ }^{2}$ ) Citties Torrent (bent t'infect

10. The hallow'd bowels of the siluer Thames)

Is checkt by strengtlh and clearenesse of the Riuers ${ }^{3}$ ),

Till it hath spent it selfe e'ene at the shore?")

So in the ample and vnmeasur'd Flood

Of her Perfections, aure my Passions drown'd:

15. And I have now a sppirit as sweet and cleere, As the most rarefi'd and subtill Aire;

With which, and witth a heart as pure as Fire, (Yet humble as the Ifarth) doe I implore, He kneeles.

0 Heawen: that Shee (whose Figure hath effected

20. This change in me) may neuer suffer Change

In her Admir'd and thappie Gouernment:

May still this Iland be call'd Fortunate,

And Rugged Treasoni tremble at the sound

When Fame shall spreake it with an Emphasis.

25. Let forraine Pollicie be dull as Lead,

And pale Inuasion ciome with halfe a heart

When he but lookes vpon her blessed Soile:

The Throat of Warree be stopt within her Land,

And Turtle-footed Pesace dannce fairie Rings

30. About her Court; where neuer may there come

Suspect or Daunger, but all Trust and Safetie:

Let Flatterie be dumibe, and Enuie blind

In her dread Presence: Death himselfe admire her:

And may her Vertues make him to forget

35. The vse of his ineuitable hand.

Page Q4 verso, Fly from her Age; Slleepe Time before her Throne,

1. 1. Our strongest wall fals downe when she is gone.

Here the Trumpets sound a flourish, in which time Macilene conwerts himselfe to them that supply the place of GFEX, and speakes.

1) Blesse misprint for Blessed.

2) our misprint for as our.

') Rivers misprint for River.

C) shore? misprint for shore,. 
5. GREX.

Mac. How now sirs? how like you it? has't not bene tedious?

Cor. Nay, we ha' done censwring now.

Mit. Yes faith.

Mac. How so?

10. Cor. Mary because we'le imütate your Actors, and be out of our Humors. Besides, here arre those (round about you) of more abilitie in Censure then we, whose iudgements can gine it a more satisfying Allowance: wee'le referre you to them.

Mac. I? is't e'en so? Well, Gentlemen, I should hane gone

15. in, and return'd to you as I wass Asper at the first: but (by reason the shift would haue bene somewhat long, and we are loth to draw your patience any farder) wee'le intreat you to imagine it. And now (that you may see I will be ont of my Humor for company) I stand wholly to your Kind Approbation, and (in-

20. deed) am nothing so peremptorie as $I$ was in the beginning: Marie I will not do as Plautus in his Amphitryo for all this (Summi Iouis causa, Plaudite:) begge a Plaudite for Gods sake; but if you (out of the bountie of your good liking) will bestow it; why, you may (in time) make leane Macilente as fat as Sir John 25. Fall-staffe.

Exeunt.

Non ego ventosa plebis suffragia venor.

If we read and reread the above without attending to the Greek intercalary sentence, we shall most probably be led to surmise that the original closing scene must have had something to do with Queen Elizabeth, but we get no clearly defined notion of the exact part which she was made to play in it: the whole thing remains wrapped up in vague halflight. Nor is there much reason to be ashamed of our inability to grasp the real situation, since none of the editors of Ben Jonson's works has up to now succeeded in reading the riddle. And yet the Greek words contain a perfectly satisfactory solution of the mystery. In them Ben Jonson informs us, that the original closing scene seemed to be distasteful to many persons, because in it the queen was made one of the dramatis personce.

Now everything becomes cllear as crystal. The original closing scene is laid at the court, just as the second scene of the fifth act. Ben Jonson left out the opening part of the original closing scene, preceding the line Blessed, divine, etc. Reasons into which we need not now enter, render it probable 
that this opening part consistted in little more than a short monologue by Macilente, of which the purport is clearly sketched out in lines 25 anid 26 of page $Q 3$ verso. Lines $27-30$ of page $Q 3$ verso them inform us of what happened next, and the rest of the original lines Ben Jonson has preserved for us entire. The unexpected personal presence of his august sovereign produced on Macilente so powerful an impression that he was curedl of his envy and thus brought out of his humour.

With perfect justice, we think, Ben Jonson speaks up for the denouement as he had origiinally conceived it. For, looking away from the venturesome experiment of bringing the queen on the stage, the original closing scene is dramatically far more effective than the weak lines (22-33 of page $Q 2$ verso) that have replaced the first version, and in which Macilente confesses himself cured of hïs envy, because there are no longer any persons to be enviied by him.

Now, however, we come to a highly remarkable circumstance. In the second edition of Every Man out of his Humour, i. e. in the Folio edition of 1616 of Ben Jonson's works, we actually get two other closing; scenes entirely different from those which we have learnt to know from the Quarto of 1600 , iwhile at the same time the rest of the play is found to be identical in the two editions, if we except the small differences by which two mutually independent impressions from the same manuscript were always distinguished at the time.

The closing scene on p. 174 of the Folio edition consists of lines 22-33 of page Q2 verso plus lines 6-25 of page Q4 verso in the Quarto edition The connection between these two parts is managed thus:

So heauen were pleas'd: but let them vanish, vapors.

Gentlemen, how like yon iit? has't not beene tedions?

\section{GREX.}

COR. Nay, we ha' dome censuring, now.

Nothing can be inferred from the small change of How now Sirs? into Gentlemen. It belongs to the class of small differences to which we have just referred. Far more remarkable it is, that the line in which this change is found 
is not in its proper place. It ought to have been printed below the word GREX, as we find it in the Quarto edition, since both its form, which is prose but is here made to simulate a blank-verse line, and its meaning, mark it as belonging to the "grex" part, and as such standing apart from the business of the play itself. We are here brought face to face with an undoubted mistake in the redaction of the Folio edition, a mistake that naturally suggests the question whether the proofs of this 1616 edition can have been submitted to Ben Jonson for revision.

Of course an isolated oversight of this nature may quite possibly fail to catch the eye of a proof-reading author, but we think it highly unlikely that the same thing should happen to him twice over. Still, this same class of redactional blundering is repeatedly represented in the Folio, in proof of which we cite another telling instance on p. 87:

CORD. O, here comes the Prologue: Now Sir! if you had staid a little longer, I meant to have spoke your prologue for you, I faith.

The third sounding.

PROLOGVE.

No one can fail to see that the stage-direction The third sounding ought to stand before or after the first two words of the passage quoted, as is actually found to be the case on page B3 verso of the Quarto edition:

. . . . . .: they sounde.

Sound the third time.

ENTER PROLOGVE.

Cor. 0 here comes the Prologue: Now sirre, if you etc.

The second closing scene found in the Folio edition follows on p. 175 ; it is headed:

Which, in the presentation before

Queene $E$. was thus varyed,

BY MACILENTE.

and consists of lines 2-36 of page $Q 4$ and line 1 of page Q4 verso. 
However incompatible this way of putting the matter may seem to be with what we learn from the quarto edition, there is always the possibility that after the appearance of the quarto, i. e. between 1600 and 1603, the year of Elizabeth's death, a performance of the play took place before the Queen, and that on this occasion Ben Jonson again availed himself of the original text.

On this supposition, however, it must appear highly remarkable that Ben Jonson should have cancelled the four opening lines:

Blesse(d), Diuine, Vnblemisht, Sacred, Pure,

Glorions immortall, and indeed Immense;

0 that I had a world of Attributes,

To lend or adde to this high Maiestie:

of Macilente's address to the Queen transformed into an epilogue. We find it hard to believe that the poet who had used these lines in a speech addressed to a stage-queen, should have left them out when he had to compliment Queen Elizabeth in propria persona. Meanwhile, Gifford thus delivers himself with respect to these omitted lines:

This spirited and poetical Epilogue .... was prefaced by four lines of absurd and fulsome rant, bordering on profaneness. It is to the praise of the audience, that, though accustomed to hear the queen addressed in terms of the grossest adulation, they yet murmured at this, and expressed their dislike so strongly as to draw from Jonson an awkward attempt at justification. Neither the verses, nor the apology for them, call for preservation; the former were rejected by the author, and the latter appeared only in the quarto. Jonson was undoubtedly ashamed of both.

From this we see that Gifford, whose numerous Greek quotations cited in illustration of Ben Jonson's dramas show him to have been desirous of impressing readers with his familiarity with Greek, has utterly failed to understand the drift of page $\mathrm{Q} 3$ verso in the quarto edition. As we have seen, Ben Jonson defends there, not the four lines which are wanting in the Folio edition, but the propriety of bringing the Queen on the stage. And if Jonson had been ashamed of these four lines, he would of course have omitted them already from the quarto edition. Regard being had to the time in which they were written, there is really nothing 
peculiar about these lines; Edmund Spenser used to write in exactly the same strain, e.g. The Teares of the Muses, 1.579:

Dinine Elisa, sacred Emperesse:

But there is more behind. If Ben Jonson had for some reason or other deemed it expedient to cancel the four lines in question, he would most certainly have replaced them by something else, for the beginning of the Epilogue as it now stands in the Folio, is far from clear and intelligible, since the audience are left completely in the dark as to what or who is meant by the word object, and who is referred to by the word her, in the first six lines following:

Neuer till now did obiect greet mine eyes

With any light content: but in her graces,

All my malicious powers have lost their stings.

Enuie is fled my soule, at sight of her,

And shee hath chac'd all black thoughts from my bosome,

Like as the sunne doth darkemesse from the world.

Every one who gives himself the trouble of attentively reading these six lines, must inevitably arrive at the conclusion, that the redaction in the Folio edition cannot be correct, and cannot have originated with Ben Jonson himself. If the play had actually been performed in the Queen's presence, Macilente could never have said in the epilogue that "at sight of her" Envy had fled from his soul, for in that case Macilente must have seen the Queen from the very beginning of the performance. The sudden revulsion wrought in Macilente by the unexpected appearance of the august personage of Queen Elizabeth would have become a sheer impossibility.

There is still another passage in this epilogue which furnishes absolute proof that the arrangement in the Folio edition cannot have been Jonson's work. In line 20 of page Q4 a highly characteristic change has been made, so that the Folio text is made to run as follows:

$$
\text { . . . . . I implore }
$$

0 heauen, that shee (whose presence hath effected This change in me) may suffer most late change

In her admir'd and happie gouernement:

According to the Folio text in 1.20, Macilente would be made to express a wish that a change might come over the 
Queen's admired and happy government, a "most late change" to be sure, but a change all the same. This would have been absurd to a degree. Hiere too, only the quarto text can

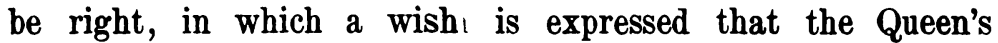
government may never suffer change. We need hardly add that a queen's death does not make a change in her government, but puts a period to hier life.

The arbitrary change in the Folio version just discussed, is instructive also in that we see from it that the person who made it, can have bestowed bout scant attention on the original Quarto text. For only whem we read that shee may neuer suffer change without attendiing to the necessary limitation in the next line In her Admirr'd and happie Gouernment, can the change to suffer most latte change seem to be a real improvement of the text, because only in that case to suffer change could be interpreted tto mean "to depart this life".

The presence of the two new closing scenes in the Folio edition, of which scenes as wee have seen the redaction cannot have originated with Ben Jonison himself, may be readily and unforcedly accounted for by the obscurity of the Quarto text in this place. Nothing, indeeed, is more natural than that the editor or printer of the Foliio edition, who was undoubtedly ignorant of Greek, should hiave thought himself justified in inferring from Macilente's adıdress to the Queen, that a performance of the play in the Queen's presence had actually taken place.

Our criticism of the teext inexorably relegates to the dreamland of fiction this allesged performance of Every Man out of his Humour before Queen Elizabeth. Even in itself, it would have been improbablle that Queen Elizabeth between 1600 and 1603 should have honoured with her presence a comedy by Ben Jonson whiclh had proved a failure on its first performance. In point off fact, the only evidence we have for such presence is the testimony of the Folio edition. And on this testimony alone do later authors base themselves. Thomas Davies, for instance, in his Dramatic Miscellanies, etc., Vol. II, p. 77, thus embroiders; the story in 1783 :

This comic satire gave greneral satisfaction. Queen Elizabeth, drawn by the fame which was spread of it, honoured the play with her presence. Jonsosn, to pay a respectful compliment to 
his sovereign, altered the conclusion of his play into an elegant panegyric, spoken by Malicente ${ }^{1}$ ); which turns upon this simple idea; that her majesty's powerful influence had converted him, the representative of envy, into a contrary character. Mr. Collins, the author of several justly-esteemed poems, first pointed ont to me the particular beauties of this occasional address.

\section{Professor A. W. Ward in A History of English Dramatic} Literature, 1875, Vol. I, p. 521, is a good deal soberer:

We have no record from his own lips in reference to the period of his life coinciding with the remainder of Queen Elizabeth's reign. The Queen witnessed his Every Man out of his Humour, and to honour the occasion he composed the 'Epilogue at the Presentation before Queen Elisabeth'. Whether Lord Falkland's assertion that the Queen

With her judicious favours did infuse

Courage and strength into his younger muse.

was based on any substantial proofs of the royal goodwill may be doubted.

Lord Falkland's lines, cited by Ward, occur in a poem which the noble author contributed to Jonsonus Virbius: or, the Memory of Ben Jonson. Revived by the Friends of the Muses, brought out in 1638, about six months after Jonson's death. Lord Falkland was born in 1609 or 1610 , and it is altogether uncertain, though just possible, that in these two lines he is referring to the alleged performance of the play before Queen Elizabeth. If this should be the case, he again can only base himself on what he must have read in the Folio edition.

It remains for us to account for the absence from the Folio of the first four lines of Macilente's address to the Queen, which we have cited on pp. 381 and 385 . In Queen Elizabeth's time the use of profane language was "good form". The Queen herself set the example - God's death was her favourite oath - and the plays of the time, which, as plays are apt to do, held the mirror up to nature, and shewed the very age and body of the time his form and pressure, in many cases swarmed with all sorts of ingeniously diversified blasphemies. All this changed when James I mounted the throne. Soon after his accession cases of profane swearing on the stage

1) Corrected to Macilente in the second edition of 1785 . 
were punished with a fine off ten pounds sterling. From that time the number of oaths allso in the printed plays began to diminish, not only in such aas appeared for the first time, but also in the reprints of olderr pieces. Of this state of things Every Man out of his Humovar furnishes a striking illustration. The Quarto edition of 1600 (contains about a hundred profane oaths. In the Folio edition of 1616 a few of these "swearwords" have been altogetheer omitted, a small number only have been left unchanged, lbut the great majority of them have been softened or improoved away. But the perfunctory, inconsistent, mechanical, someetimes even puerile way in which this kind of correction took place, furnishes additional proof that Ben Jonson can have bomrne no part in the press-correction of the Folio of 1616.

The same spirit that thhought itself called upon to omit or alter the profanities in the play, took umbrage at the four lines in question and cancellied them. We repeat that if Ben Jonson had himself sacrificed them, he would undoubtedly have replaced them by something else.

Gifford, the best known aamong the editors of Ben Jonson's works, says of the Folio edittion:

I am not quite sure thaat the concluding pages ${ }^{1}$ ) enjoyed the benefit of Jonson's superiintendence; but as by far the greatest portion of the volume unndoubtedly did, it is come down to us one of the correctest woprks that ever issued from the English press.

Cunningham, a subsequernt editor of Ben Jonson, says: Gifford cannot praise the 1616 folio too highly, . . . . .

Professor C. H. Herford ssays, Dictionary of National Biography, Vol. XXX, p. 190:

Jonson's 'Works' were fifirst collected in the folio edition, of which the first volume, c carefully revised by himself, appeared in $1616, \ldots \ldots$

In the foregoing pages wwe have proved for Every Man out of his Humour, that the authorities are mistaken as regards the exceptional valuae of the Jonson Folio of 1616. Elsewhere in this Folio we haave detected blunders as indubi-

1) These "concluding pages" haave nothing to do with Every Man out of his Humour. The Folio has 1015 i pages, and this play covers pp. 73-176. 
table as those we have been discussssing. For the purposes of the present paper it is needless to , enlarge upon them, since the instance we have given is so tellling that no one can any longer believe in the character for exxceptional exactness which the 1616 Folio has hitherto enjoyedd.

If in conclusion we put the quaestion what authority must be assigned to the Quarto and tao the 1616 Folio texts of Every Man out of his Humour, andd how these two texts are mutually related, the answer need i not be doubtful. Both the texts were printed from the author's's manuscript, but corrected by the printer, or by the press-readeer employed by the printingoffice, in accordance with the usuall practice of the time, i. e. the corrector made arbitrary changees wherever he took it into his head to do so. ${ }^{1}$ )

That the quarto text was actuallly printed from the author's manuscript, and had nothing to do , with stage-copies or other sources of a more or less dubious chaaracter, may with certainty be inferred from certain facts, of whhich the two following are in themselves decisive:

1. The title-page of the Quarto eddition says: "As it was first composed by the Author RB. J. Containing more than hath been publikely spokenn or acted."

2. Page Q3 verso, which we hhave in extenso quoted on p. 380 supra, contains utterrances by the author himself of so peculiar a character $r$, that we are irresistibly led to conclude that Ben. Jonson himself must have handed over his manuscrippt to the printer.

The exceptionally large numbeer of misprints - of which the reader has had various specimaens brought to his notice in our quotations - and besides, the e nature of certain of these misprints, give us a right to connclude that Ben Jonson no more read the proofs of the Quartao edition than he did those of the Folio.

That the Folio text must alsiso have been printed from Ben Jonson's manuscript and cannnot be a reprint from the

1) For ampler information on this s?special point we would refer the reader to William Shakespeare: Prosody, and Text, Leyden 19ro, to our Heywood paper in the Shakespeare Jahrbwuch for 1902, and to our Chapters on English Printing, Prosody, and Pronmunciation, Heidelberg, 1902. 
Quarto text, is proved by y various circumstances of which we specify the following:

1. The two texts have nno characteristic mistakes in common with each other.

2. A whole group of textual differences, of which we have given an instance o1on p. 384, cannot possibly be accounted for on the assumptition that the Folio was printed from the Quarto, but addmit of a very easy explanation if we assume that both । texts were printed from the manuscript. In dramatitic manuscripts, namely, stage-directions like third soiounding, (Enter) Prologue, etc. are always placed in $t$ the margin, so that the printer runs frequent risks of aassigning to such a direction too high, but especially toon low a place on the page he is setting up.

3. The number of apoststrophes is much larger in the Folio than in the Quartcto. It would not seem to be a matter of common knowleledge that Ben Jonson himself tells us in his Grammnar, that apostrophes were "many times, through the e negligence of Writers and Printers, ... quite omitted",", from which we may conclude that the wealth of apost3trophes in the Folio text cannot have arisen from their I paucity in the Quarto version.

Strictly speaking, it is s hardly necessary to put the question whether the Folio text caan have been printed from stagecopies. Only Ben Jonsomn himself can have furnished the printer with the necessaryy material for the contents of the 1616 Folio, and it goes wwithout saying that Ben Jonson had no stage-copies at his dispposal.

As against the Folio tetext, the Quarto text is characterised by a glaring perfunctorinesess of correction apparent from the very large number of misisprints, including small omissions. On the other hand, this veryy negligence of correction guarantees a much greater trustworthhiness of the Quarto as against the Folio in cases where theyy deviate from each other; see, for instance, How now sirs and Gentlemen on p. 383. For the less time and care have been bibestowed on the correction, the less will be the number of worrods and phrases which the corrector has arbitrarily changed. The very absence, so to say, of 
misprints in the Folio, which has ledd superficial modern editors to rate its authority so high, and too assume correction of the Folio by the author himself, must l be looked upon as a very suspicious circumstance the moment it is proved beyond doubt that the author was not at the samne time his own corrector.

The only consideration that coould induce us to assign a higher authority to the divergent rreadings of the Folio than to those of the Quarto, would havve to base itself on the hypothesis that after the printing cof the Quarto Ben Jonson had here and there made correctionns or changes in his manuscript. Up to now we have not lilighted upon anything that would in reason render such an hhypothesis probable or acceptable. A very small number off variant readings in the Folio text (apart of course from 'what must be considered original readings as against the neggligences and misprints of the Quarto) strike us as real improvvements, but these evident improvements are so few in numberr that there is no reason not to ascribe them to the corrector.. In William Shakespeare: Prosody and Text, we have laid s6ome stress on the fact which after all cannot greatly asttonish us - that the correctors of the press now and then 1 had lucid moments, even though on the whole their activity must be looked upon as a national calamity.

We conclude that henceforth eeditions of Every Man out of his Humour should no longer bee based exclusively on the Folio text of 1616, as has invariabbly been the case hitherto.

Of Ben Jonson's plays, no moore than of Shakespeare's dramas or of the works of any of their contemporaries, do we up to now possess a single ediition in which the results of a scholarly criticism of the text lhave been properly utilised.

The Hague.

NYMEGEN.

Bastifian A. P. Van Dam. CloRNelis STOFFeL. 